\title{
高速道路盛土建設における軟弱地盤対策の変遷 \\ HISTORICAL ASPECTS OF COUNTERMEASURES FOR \\ EXPRESSWAY'S EMBANKMENTWORKS ON THE SOFT GROUND
}

\author{
持永龍一郎* - 栗 原 則 夫** ・ 瀬 在 武*** \\ By Ryûichirô MOCHINAGA, Norio KURIHARA and Takeshi SEZAl
}

\section{はじめに}

日本道路公団では，これまで全国各地で様々な軟弱地 盤に遭遇し，多くの試行錯誤を繰り返しながら軟弱地盤 対策の技術を発展させてきた.

名神高速道路における軟弱地盤対策は, 土質力学の忠 実な適用から始まったが，尼崎，乙訓，大垣の各試験盛 土の実測データの示すところを事実として認めるところ から計算万能主義を脱却し, より実用的な設計, 施工指 針を得ることができた. 東名高速道路では名神とは比べ ようがないくらい多種多様の軟弱地盤に遭遇することに なり，軟弱地盤対策の技術も多くのノウハウの蓄積によ って幅を増し，ここに道路公団独自の軟弱地盤対策の技 術の基本が確立された. その具体的内容は昭和 45 年 1 月の「日本道路公団設計要領・第 1 集」に集約された.

新規縦貫五道の建設段階に入ると, 高速道路は全国一 展開することとなり, 軟弱地盤対策は「昭和 45 年版設 計要領」技術の応用の時代に入った. 東北道, 北陸道の 軟弱地盤対策を皮切りに, 九州道, 京葉道路, 東関道な ぞを経て道路公団の軟弱地盤対策の技術はさらに磨か れ, 常磐道, 道央道において新しい段階に到達した. そ して, それは昭和 58 年 4 月の「日本道路公団設計要 領・第1集」としてまとめられた．以上のような経緯の 中で道路公団が全国で遭遇した主な軟弱地盤の分布は 図一1 のとおりである.また，これらの軟弱地盤におけ

\footnotetext{
* 正会員 日本道路公団 東京第二建設局長

** 正会員 工修 日本道路公団 新潟建設局糸魚川工事事務 所長

*** 工修 日本道路公団試験所 土工試験室長 （广194/東京都町田市忠生 1-4-1)
}

る土工工事の年代的な経過は 表一1 のとおりである.

以下, 道路公団における軟弱地盤対策の技術, 寸なわ ち, 軟弱地盤における高速道路盛土の設計, 施工技術の 変遷を, 名神および東名高速道路時代とそれ以後に分 け，技術的にみてエポックメーキングな事例あるいは技 術的に特色のある事例を中心に取り上げながら，述べる こととする.

\section{1. 名神および東名高速道路}

\section{（1）試験盛土方式の導入}

名神高速道路で初めて遭遇した軟弱地盤は, 尼崎地区 であり, 続く乙訓地区であった.すべてが初めての経験 であり，多くの問題点を机上で解決できる技術もなく， その実際的な問題解決法として実物大の試験盛土を実施 するといら方式が採用された. 尼崎㐨よび乙訓地区でサ ンドドレーン区間（尼崎ではサンドンパクンョンパイル区間も） と何も対策工を施さない無処理区間が設けられ, 試験盛 土が施工された. 得られた沈下データは, サンドドレー ンを打っても打たなくても同じといら結果を示してい た.しかしながら土質力学は万能と考えられ, 実測結果 の如何よりも計算結果の方が信頼されていたので, 本線 工事ではサンドドレーンが採用された。このように摇藍 期の技術的未熟さはあったものの, 問題解決の手段とし て試験盛土方式を導入し，乙かも処理区間と無処理区間 を直接比較するといら手段を最初から採用したことは, 軟弱地盤対策の技術の発展にとって画期的なことであっ た. この思想は後々まで引継がれ，対策工の効果を定量 的に評価する実際的な方法として大きな貢献をすること 
凡例

一供用区間

=施工区間

$=====$ 基本計画区間

— 予定路線区間

沖積層の分布

(昭和 59 年 7 月 30 日現在)

\begin{tabular}{l|l}
\hline No. & \multicolumn{1}{|c}{ 地 区 名 } \\
\hline (8) & 柏崎・上越 \\
\hline (9) & 小 杉 \\
\hline (10) & 小松東 \\
\hline (11) & 加 賀 \\
\hline (12) & 湖 北 \\
\hline (13) & 日 立(神田 TF) \\
\hline (14) & 谷和原・谷田部 \\
\hline (15) & 佐 原 \\
\hline (19) & 佐 倉 \\
\hline (17) & 館 林 \\
\hline (18) & 加 須 \\
\hline (19) & 岩 槻 \\
\hline (20) & 宮野木 \\
\hline (21) & 星久喜 $(\mathrm{TF})$ \\
\hline (22) & 厚 木 $(\mathrm{TF})$ \\
\hline
\end{tabular}

\begin{tabular}{|c|c|}
\hline No. & 地 区 名 \\
\hline (23) & 愛 甲 (TF) \\
\hline (24) & 骤 訪 \\
\hline (25) & 焼 津 \\
\hline (26) & 袋 井 $(\mathrm{TF})$ \\
\hline (27) & 大 垣 (TF) \\
\hline (28) & 長 島 \\
\hline (29) & 乙 訓 (TF) \\
\hline (30) & 尼 崎 $(T F)$ \\
\hline (31) & 八 幡 (直方) \\
\hline (32) & 武 雄 \\
\hline (33) & 溝 陸 \\
\hline (34) & 御 船 (松橋) \\
\hline
\end{tabular}

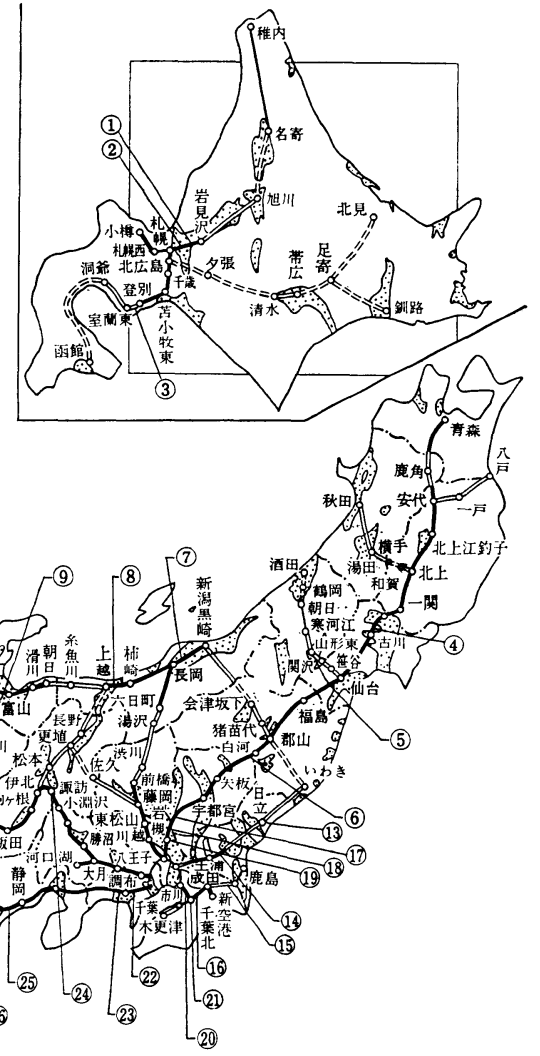

図一1高速道路で施エした主な軟弱地盤地区

表一1 軟弱地盤における土工工事の年代経過

\begin{tabular}{|c|c|c|c|c|c|c|c|c|c|c|c|c|c|c|c|c|c|c|c|c|c|c|c|c|c|}
\hline 道路名 & $\begin{array}{lll}33 & 34 & 3 \\
\end{array}$ & 35 & 36 & & 38 & 39 & 40 & 41 & $42^{\text {年 }}$ & 43 & $\dot{4}$ & 45 & 46 & 47 & 48 & 49 & 50 & 51 & 52 & 53 & 54 & 55 & 56 & 57 & 58 \\
\hline $\begin{array}{c}\text { 名 神 } \\
\text { (名神高速道路) } \\
\end{array}$ & $\underbrace{\text { 尼崎 TF }}$ & 䚯 & & U. U. & 訓, 大 & & & & & & & & & & & & & & & & & & & & \\
\hline $\begin{array}{c}\text { 東 名 } \\
\text { (東名高速道路) }\end{array}$ & & 大坦 & & & 厚术 & $\mathrm{TF}$ & 厚标; & 烧津, & 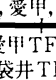 & & & & & & & & & & & & & & Б見 & & \\
\hline $\begin{array}{c}\text { 道 央 道 } \\
\text { (道央自動車道) }\end{array}$ & & & & & & & & & & & & & & & & & & 見泣 & & & & & $E 1$ & & 登別 \\
\hline $\begin{array}{c}\text { 東 北 道 } \\
\text { (東北自動車道) }\end{array}$ & & & & & & & & & & & & & 蕦， & & & & ( 姉 & 粎, & & & & & & & 山形 $\mathrm{TF}$ \\
\hline $\begin{array}{c}\text { 北陸 道 } \\
\text { (北陸自動道) } \\
\end{array}$ & & & & & & & & & & & & & & & & & 斩鼬, & 長岡 & & & & & & & \\
\hline $\begin{array}{c}\text { 東 関 道 } \\
\text { (東関東自動車道) }\end{array}$ & & & & & & & & & & & & & & & & & & & & 佰, & 田 & & & & 佐原 \\
\hline $\begin{array}{c}\text { 常 盤 道 } \\
\text { (常盤自動車道) } \\
\end{array}$ & & & & & & & & & & & & & & & & & & & & & & & 神田 & $\mathrm{TF}_{-}$ & \\
\hline $\begin{array}{c}\text { 中 央 道 } \\
\text { (中央自動車道) } \\
\end{array}$ & & & & & & & & & & & & & & & & & & & & 諏 & 斿 & & & & \\
\hline $\begin{array}{l}\text { 京 葉 道 } \\
\text { (京葉道路) }\end{array}$ & & & & & & & & & & & & & & & & 星久喜 & 都儿 & & & & & & & & \\
\hline $\begin{array}{c}\text { 東 名阪 } \\
\text { (東名阪自動車道) }\end{array}$ & & & & & & & & & & & & & & & 長鳥 & & & & & & & & & & \\
\hline $\begin{array}{c}\text { 九 州 道 } \\
\text { (九州自動道) }\end{array}$ & & & & & & & & & & & & & & & & 御 船 & & & 幡 & & & 熱 & & & 武雄 \\
\hline
\end{tabular}


になった。

\section{（2）動態観測の定着化と計算万能主義からの脱却}

名神高速道路の名古屋周辺の調查が進むにつれて, 濃 尾平野, とくに大垣地区が今までと比較にならない大規 模な軟弱地盤であることが明らかになってきた. 尼崎, 乙訓の試験盛土で露呈されたいくつかの問題点に決着を つけるべく大がかりな試験盛士が実施された。すなわ

表一2 試 験 区 間

\begin{tabular}{cc|c|c|c|c}
\hline 区 & 間 & A & B & C & D \\
\hline 処 理 エ & \multicolumn{3}{|c|}{ サントトレーン } & 非改良 \\
\hline 打設ピッチ & $2.4 \mathrm{~m}$ & $2.4 \mathrm{~m}$ & $1.6 \mathrm{~m}$ & - \\
\hline 打 設 長 & $8 \mathrm{~m}$ & $20 \mathrm{~m}$ & $8 \mathrm{~m}$ & 一 \\
\hline
\end{tabular}

合 水 比 $\omega_{n}(\%)$

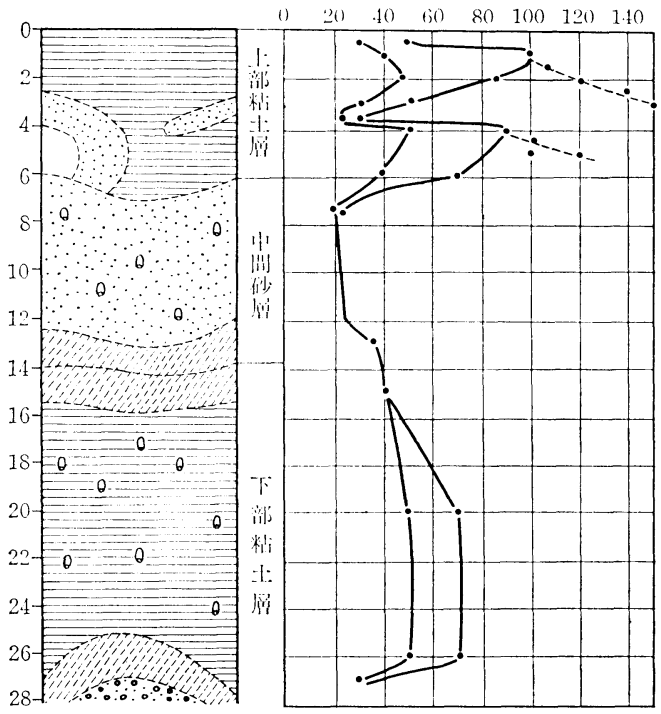

(m)

図一2 大垣地区士質柱状図
ち, この大垣試験盛土では, サンドドレーンの沈下促進 効果を確認することを主目的に, 表一2 のような 4 つの 試験区間が設けられた. 各区間の延長は $50 \mathrm{~m}$ 前後, 総 延長は $170 \mathrm{~m}$ であり, 盛土高はすべて $8 \mathrm{~m}$ とした. 試 験区間の土性は 図一2に示すとおりである．綿密な動態 観測網を設けて盛土が施工された. その結果得られた沈 下時間曲線は図一3のようである. 沈下量の大きさには 区間ごとにいくらかの差はあるが，時間的変化の傾向に はいずれも有意差がないことが歷然と現れた.

このように万全の観測体制が敷かれ，十分に計画の練 られた大垣試験盛土において, 尼崎, 乙訓と同様にサン ドドレーン区間と無処理区間の沈下傾向に有意差が生じ ないことが実測されるに及んで, 理論が実際と一致しな い事実を直視せざるを得なくなった．計算だけによると いくらか安定上の疑問も残していたが，本線工事ではサ ンドドレーンを採用せず無処理のまま盛土することに踏 み切った。

このことは，それまでの常識すなわち軟弱地盤にはサ ンドドレーンといら概念を打ち破り, 計算万能主義から 脱却することになった画期的な決断であった.

このように理論の束縛から逃れる根拠を与えてくれた のは, 動態観測による実測データであった.この大垣地 区における経験は，動態観測を行いながら実測データに 基づいて技術的な判断を下していくというやり方を，道 路公団における軟弱地盤対策の一般的な技術として定着 させることとなった。

なお，大垣地区の本線工事では，沈下促進および残留 沈下軽減のためのサーチャージ工法の採用, 橋台取付部 の高盛土区間へのサンドュンパクションパイル工法の採 用, プレロード施工による浮基礎式のカルバートの採用 等, その後の東名高速道路での設計, 施工の原則となっ た考え方が採用された。

また，大垣地区は供用後の残留沈下が大きいことが予 想されたので，暫定舗装 (ハインターコースまで施工) とした.

\section{（3） サンドドレーン効果の確認}

昭和 38 年になると東名高速道路の調查も本 格化してきた．まず最初に問題となったのは相 模川流域の厚木地区であった．大垣地区ょり条 件の悪い軟弱地盤と考えられ, さっそく試験盛 土が実施された。サンドドレーンのほかペーパ 一ドレーンも試験されたが，名神地区と同様沈 下促進効果は認められなかった.

厚木地区の隣の名古屋寄りにある愛甲地区 は, 含水比が最大で $700 \%$ に達する泥炭層を 含んだ軟弱地盤で, 層厚は $10 \mathrm{~m}$ 前後であっ 

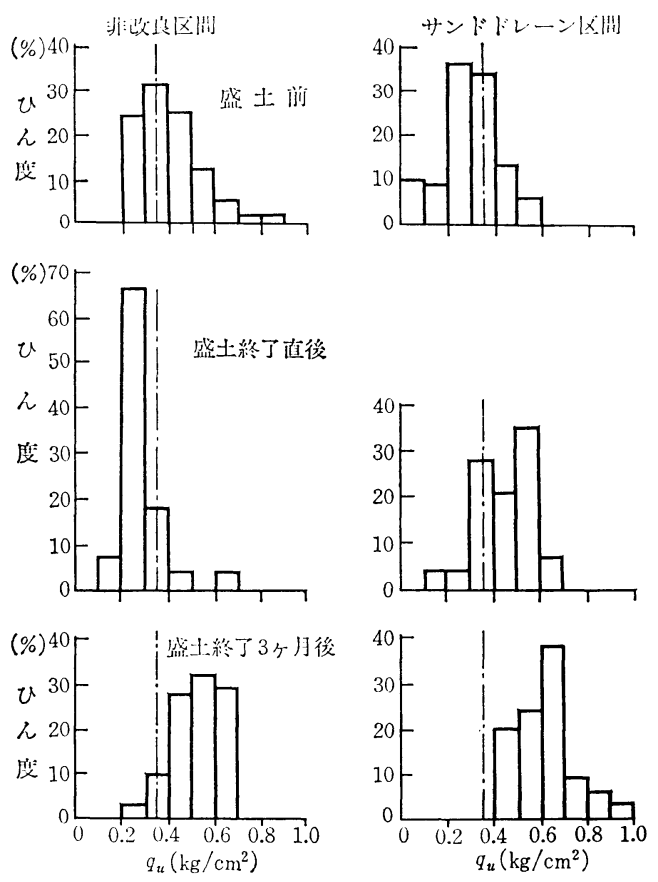

図-4 土の強度の時間的変化（愛甲試験盛土）

た.このような本格的な泥炭地盤に遭遇したのは高速道 路の建設が始まって以来初めてのことであり, 盛土の安 定の確保がきわめて困難と予想されたので試験盛土が実 施された. 観測結果をみると, やはり泥炭地盤の場合も サンドドレーンの沈下促進効果は認められなかった. し かし，この愛甲試験盛士ではチェックボーリングを何回 か実施し, 地盤強度の変化が詳しく調查された. それに よると, 図一4 に示すようにサンドドレーン区間では無 処理区間より早期に強度増加することが認められた. そ れまでの試験盛土でもこらした傾向は大体認められてい たが, データ不足で結論を下すまでには至っていなかっ た.

この愛甲試験盛土において「沈下促進効果は認められ ないが, 強度増加促進効果は認められる」というサンド ドレーン効果の評価が確定したのである.この愛甲地区 の本線工事では, 安定確保を主目的にサンドコンパクシ ョンパイルを用いることとした. さらに，とくに層厚の 厚い歌川地区では避溢橋を兼ねた延長 $330 \mathrm{~m}$ の高架橋 とした.これは軟弱地盤対策として構造物が登場した初 めてのケースであった.

\section{（4）安定上問題のあった地盤における対策}

東名高速道路の静岡県内には各所に軟弱地盤が存在し ているが，袋井と焼津がとくに問題個所として早くから 検討の対象となっていた. 袋井の村松地区は含水比が $1000 \%$ にも達する末分解紪維質の泥炭層があること,

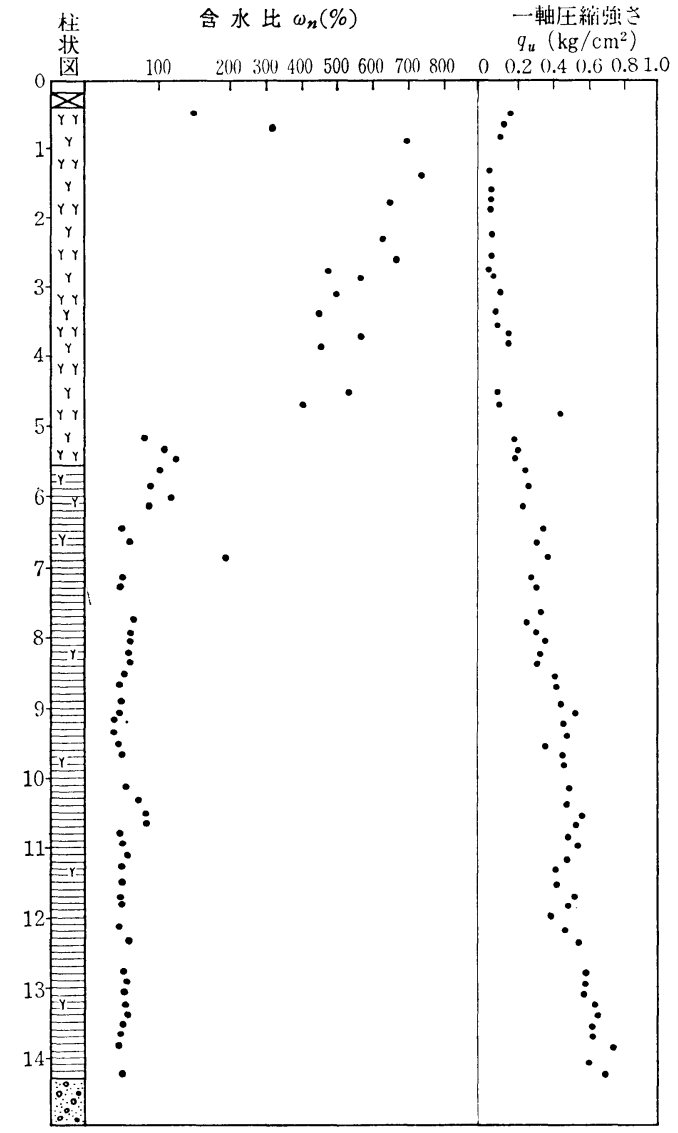

図一5 村松西地区（袋井）の地盤の土性

焼津の高崎地区は有機質粘土と海成粘土が中間砂層なし に厚さ $30 \mathrm{~m}$ 近く堆積していることが問題となっていた. 村松地区は試験盛土の結果，本線はほとんどを高架構 造とし, 盛土区間はごく一部とした. 村松地区のらち村 松西地区と呼ばれる約 $130 \mathrm{~m}$ の区間は，その盛土区間 であった. その土性は, 図一5に示すように, 表層の泥炭 層約 $5 \mathrm{~m}$ の下位に有機質粘土が $10 \mathrm{~m}$ 以上堆積してい る. 押え盛土とサンドュンパクションパイル, サンドド レーンを用いて盛土を施工したが，盛土高 $6 \mathrm{~m}$ ですべ り破壊を生じた.この地区は最終的には強制置換で対処 したが，東名の土工でもっとも苦労した軟弱地盤となっ た. 焼津の高崎地区はいわゆるオボレ谷地形になってい て, 上部 $12 \mathrm{~m}$ が含水比 $150 \%$ 程度の有機質粘土層で, 下部約 $20 \mathrm{~m}$ は含水比 $50 \%$ 程度の海成粘土層である (図一6). そしてこの地盤はフォイルサンプラーによっ て採取された連続試料から，中間砂層を含んでいないこ とがわかった. 対策工法として, 深さ $7 \mathrm{~m}$ と $20 \mathrm{~m}$ の ペーパードレーンを $90 \mathrm{~cm}$ ピッチで交互に打設し, のり 面部にはサンドコンパクションパイルを用いた. 盛土を 開始したところ, 盛土高 $8 \mathrm{~m}$ 近い時点で急に沈下量が 


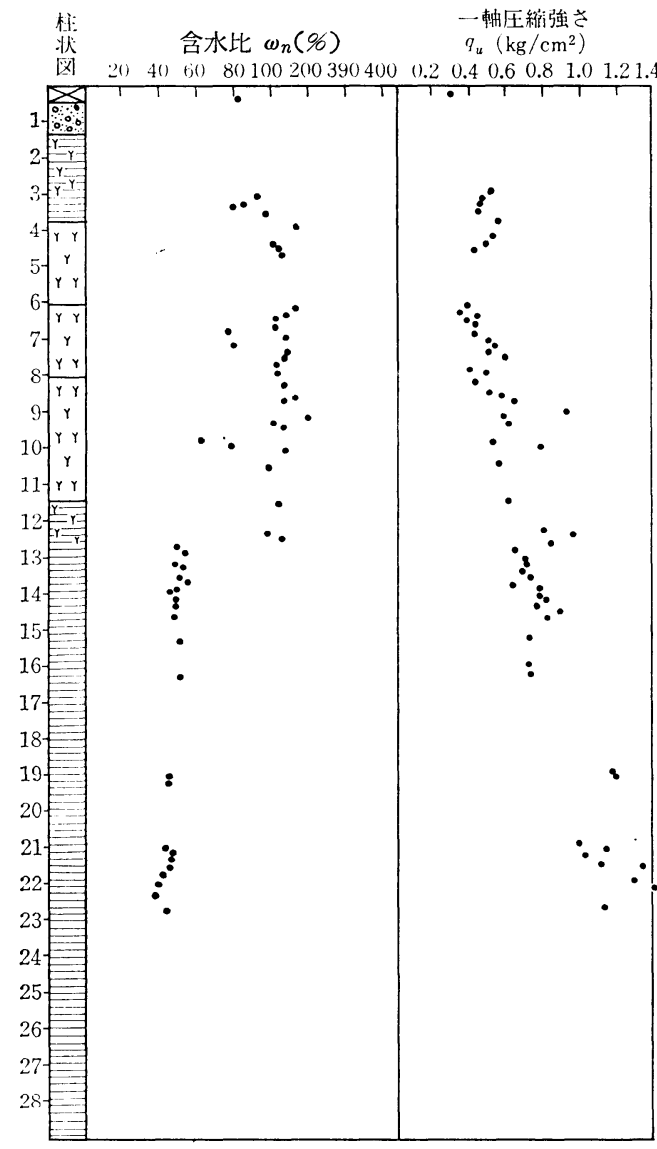

図一6 高崎地区（焼津）の地盤の土性

増大する現象が生じ, 下部の海成粘土層を通る哚いすべ り破壊を生じかけたものと推定された.この高崎地区は 供用後大きな残留沈下を生じている個所となった（図一 7).

さらに，本線工事段階で当初の予想以上に問題のある 軟弱地盤として盛土の安定確保に苦労した個所も少なく ない，たとえば，江尾地区や岩㴊地区では盛土のすべり 破壊を生じたが，これらはいずれも基盤が傾斜した所 盛土したケースであり, 基盤の傾斜方向へすべりが生じ た. 前述した村松西地区も同様に基盤が傾斜していたケ ースであった。

以上述べた村松地区と高崎地区のような上層に泥炭が あり，下層に海成粘土があるような土層構成の軟弱地盤 および基盤が傾斜しているという条件は, 破壊事例に共 通する要因であることが指摘できる.

\section{（5）新工法の試み}

東名高速道路における軟弱地盤対策としては, 押え盛 土, バーチカルドレーン, サンドュンパクションパイル, サーチャージ，プレローディングなどが一般的に用いら
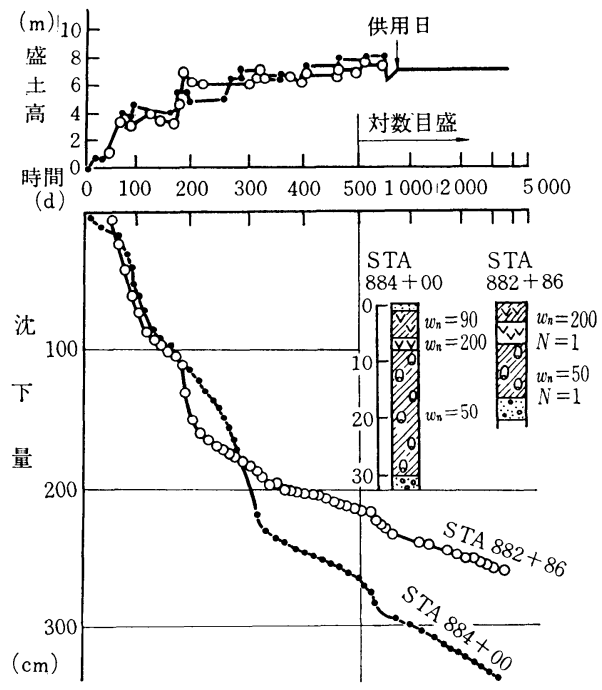

図一 7 高崎地区 (焼津) の長期沈下

れたが，試験的にあるいは特殊なケースに種々の新工法 が試みられた。

厚木地区の橋梁取付部では, 残留沈下対策のため当時 新工法として登場した生石灰パイル工法が試験的に用い られた. 構造物を軟弱地盤対策として用いた例として, 愛甲地区と村松地区の高架橋の例があることはすでにに 述べたが，村松地区の横井避溢橋，焼津地区の石脇およ び坂本避溢橋は，プレローディング工法で地盤改良した うえ，基礎杭を持たない連続カルバートボックス型式で 施工された。

愛甲地区における施工段階では，すでに名神の供用後 の状況が分かりつつあり，それによると残留沈下が大き く橋梁と盛土の取付部の段差の補修がなかなか難しい作 業であることがわかってきていた，そこで，カルバート ボックスの場合と同様に橋台部にもある程度の沈下を許 容する構造, すなわち基礎に杭を用いない構造を採用 し, 盛土部との相対的な沈下差をなくして路面の平担性 を保とうという考え方が登場した.アプローチクッショ ン方式の橋台である.

\section{（6）設計要領の確立}

名神および東名高速道路の経験により道路公団におけ る軟弱地盤対策の設計, 施工の考え方はほぼ確立され, 昭和 45 年 1 月に制定された「日本道路公団設計要領 ・ 第 1 集」にまとめられた. その要点を列挙すると, 次の とおりである。

(1) 盛土の安定検討は土の 強度増加を期待する $\phi_{\boldsymbol{u}}=$

0 法による円弧すべり計算によるものとし, 盛土立 上り時点の安全率を $F_{s} \geq 1.25$ とする.

(2) 沈下検討はテルツァーギの圧密理論，およびバロ 
ンのサンドドレーン理論を用いるものとし，残留沈 下量は一般盛土部で $S_{r} \leq 10 \mathrm{~cm}$, 橋台取付部で $S_{r}$ $\leq 30 \mathrm{~cm}$ とする.

(3) 対策工法は安定確保のためにサンドドレーンエ 法, 押え盛土工法を中心に選定し, それで安定が確 保できないときはサンドコンパクションパイル工法 等を用いる.

(4) 沈下促進のためにはサーチャージ工法やプレロー ディング工法を用い，できるだけ放置期間を長くと る.

(5) カルバートはプレロードを施工し，基礎工を用い ない構造とする。

(6) 施工時には動態観測を実施し, 安定管理, 沈下管 理を行う。

以上は名神, 東名の豊富な経験に裏付けされたきわめ て実際的な要領であったが，沈下量を計算だけで定量的 に予測することはきわめて難しく，また，新しい計算方 法の提案もできないまま慣用的な計算方法を踏襲したた め問題点も含んでいた. たとえば，上記 (2) の残留沈下 規定を設けたことにより，沈下促進のためにバーチカル ドレーンを用いても有効ではないといら結論が出ていた にもかかわらず，計算上残留沈下を規定值以下に収める ためサンドドレーンを設計するといら矛盾を後に残すこ ととなった.

\section{2. 新規縦貫五道以降}

\section{（1）ローコスト化の努力}

東名高速道路完成後, 高速道路の建設は全国へ展開す ることになったが，その中でも東北，中央，北陸，中国 および九州縦貫自動車道などのいわゆる新規縦貫五道が 優先的に整備されることになった．短期間に全国的な高 速道路網を整備するために，何よりも建設費の低减が要 請された。

軟弱地盤対策もローコスト化が必要とされた. 東北道 (岩规一館林)では盛土材の絶対的な不足といら事情もあっ て低盛土方式が大々的に採用された.このような大規模 な軟弱地盤上の低盛土の建設は, 高速道路にとって初め てのことであり，久喜試験盛土において動的荷重が基礎 地盤に及ぼす影響や盛土の変形，必要最小盛土厚などの 検討が行われた. その結果, サーチャージ工法の有効性 や路床における荷重分散のため, 路床の安定処理や良質 材の使用のほか, 盛土内の水位低下の必要性が明らかに なった.これらの結果を踏まえ, 軟弱地盤対策工として はサーチャージ工法が実施されたが, 交通荷重や盛士荷 重による不等沈下や残留沈下のため供用後の補修工事に
苦労したこと, 横断構造物が半地下ボックスとなり, 常 時地下水のポンプアップを必要としていること,などの 問題点も残った。

このほか，良質な砂が入手困難になってきたという背 景もあって, 多少条件は悪いが安価な山砂, 砕石などを サンドマットやサンドドレーンに使用することでローコ スト化を図る努力も各地で行われるようになった。 たと えば，道央道・登別地区では現地から発生する有珠軽石 がサンドマット材やバーチカルドレーン材として使える かどうか試験施工を行い，その有効性が確認されたため 本施工で全面的に使用した.

また，常磐道・谷和原地区でも，試験施工の結果を踏 まえ，砕石をバーチカルドレーン材に使用し，ローコス 卜化を図った。

\section{（2）ょり軟弱な地盤への挑戦}

東名で安定上苦労した村松地区や高崎地区の地盤は, いずれも層厚が厚く，哚層部の鋭敏な粘土層の対策をい かにするかが問題と考えられた。これに対しては，深層 (具体的沪仕 $10 \mathrm{~m}$ 以深) の粘土層は地盤処理工を施工しても 沈下・安定とも効果がないのではないか, 逆に処理工を 施工することで地盤を乱して安定上かえってマイナスに なるのではないか, などの疑問があった.

新規縦貫五道の時代に入って, それらの対応策とし て，(1) サンドドレーン， サンドコンパクションパイル 以外のたとえば生石灰パイルを施工する, (2) 地盤の乱 れの少ないサンドドレーン打設法を用いる, (3) 無処理 のままとする, (4) 高架構造とする, などが試みられた.

北陸道・加賀地区では, 哚層の粘土を生石灰パイルで 処理することが試みられた.すなわち，既往の沈下デー 夕によると軟弱層厚が $10 \mathrm{~m}$ 以浅の場合は, 盛土立上り 後, 数か月もすれば沈下はほぼ収束するが, $10 \mathrm{~m}$ 以深 の場合は，サンドドレーンを打設しても沈下が継続し管 理段階へ問題を残すことが多い.

そのため, 地表面から $10 \mathrm{~m}$ までを通常のサンドド レーンで処理し，その下位 $10 \sim 20 \mathrm{~m}$ の深い粘土層を 生石灰パイルで処理することにより，残留沈下を阻止で きるかどうかを確認するため橋台と盛土の取付部におい て現地比較試験を行った. その結果, 沈下量の絶対值は 近接するサンドドレーン施工個所よりも小さく，その有 効性が確認されたが 長期の沈下速度については, $20 \mathrm{~m}$ 以深の層の沈下が影響したためか有意な差が得られなか った.

京葉道・都川地区では, 地盤の乱れを少なくすること でサンドドレーン効果を高めることができるのではない かといらことで, 地盤の乱れの少ないオーガー式のサン ドドレーンと通常のマンドリル式のサンドドレーンの比 


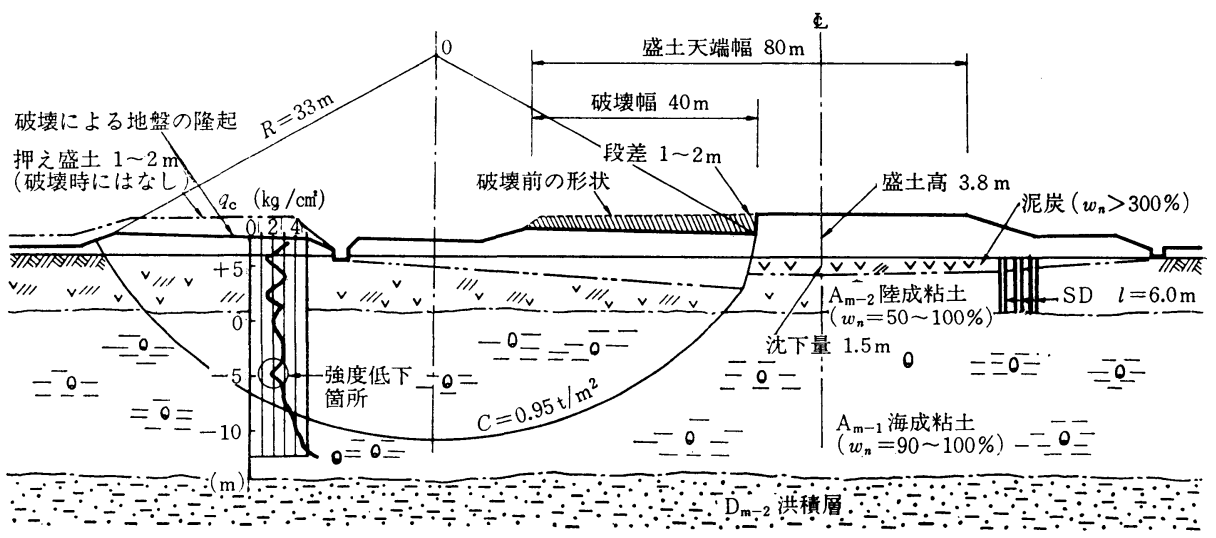

図一8 岩㚘地区すべり破壤個所横断図（Hランプ STA 1+00）

較試験が実施された. 結果的には期待したほどの沈下傾 向の差は見られず，むしろ地盤を乱すマンドリル式の方 が地盤強度増加が大きいという結果となった。

東北道・岩槻地区では岩槻インターチェンジの盛土施 エにあたり，表層の泥炭と陸成粘土 $6 \mathrm{~m}$ だけをサンド ドレーンで処理し, 深層の海成粘土は無処理のままとし たところ, 盛土高約 $4 \mathrm{~m}$ で 図一8 に示すような破壊が 延長 $130 \mathrm{~m}$ にわたって生じた. 対策工として, 縦断変 更やランプの高架部分の延長と押え盛土の大幅な追加で 復旧したが, 盛土部は供用後も過大な残留沈下が継続し ている.このように, 泥炭の下位に鋭敏な海成粘土が厚 く堆積している場合は, 盛土の安定上最も注意を要する 地盤のタイプである.

一方, 同じく深層部に海成粘土があっても, 名神の大 垣地区のように中間砂層を介在しているケースでは, 深 部の粘土層に係るような安定問題はなく, 処理の必要性 はない. しかし, 供用後の長期にわたる残留沈下は覚悟 しなければならない. 濃尾平野の低地帯に建設された東 名阪は, 大垣型の地盤であり, 避溢の条件から高架が採 用された. しかし, 長尺の基礎工となったため, 橋台部 が背面の盛土荷重による側方流動圧で変位を生じた。こ
れを契機に軟弱地盤における橋台の側方変位の研究が進 んだ.

次に, 谷地部の軟弱地盤は多くの場合, 表層部に泥炭 層を有し, 基盤が傾斜している. このような傾斜地盤上 の盛土は安定上きわめて不安定になる場合があり, 北陸 道・小杉地区や, 東北道・姉歯地区では破壊が生じた.

東関道・宮野木地区は上層に泥炭が 8 12 m, その下 位に有機質粘土が $2 \sim 8 \mathrm{~m}$ ほど堆積している. 対策工と しては，泥炭層がきわめて厚いことから，図一9に示す ようなサンドドレーン，押え盛土のほかにディープウェ ルによる地下水位低下工法を併用した. 盛土初期はウェ ルポイントを行い，その後の排水はディープウェルによ って実施した．また，水位低下の効果を上げ，かつ周辺 への影響を避けるため，周辺に矢板を打設した．実測に よる沈下量は約 $6 \mathrm{~m}$ にも達し，急速な沈下のために一 部地山との境にクラックが生じたが, 谷部全体を盛土し てしまら地形条件といら有利さもあり，土工工事期間中 に沈下はほぼ収束した。

一方，北陸道・柏崎 (刈羽) 地区は，泥炭層が約 $13 \mathrm{~m}$ と非常に厚く，その下位に有機質粘土が堆積し，しかも 基盤が傾斜した谷の端部へ盛土する条件にあったため,

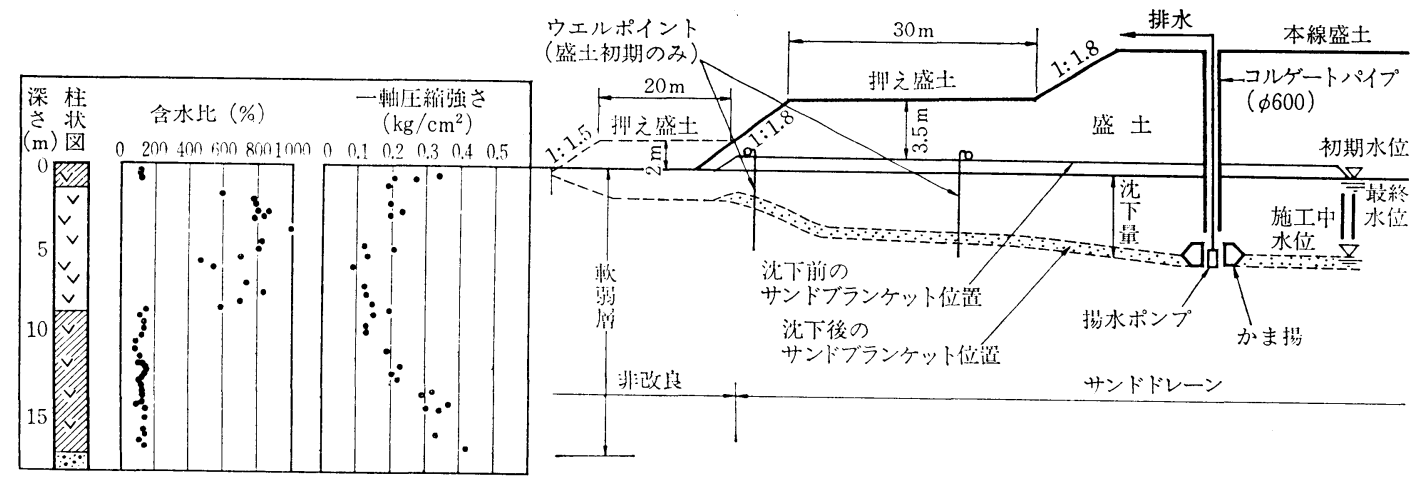

図一9＼cjkstart宮野木地区の土性および揚水方法 
安定上きわめて問題となる地盤であった．対策工として は，サンドドレーン，押え盛土およびディープウェルを 併用したが施工中に破壊し, 供用後も過大な沈下が継続 している.

\section{（3）残留沈下量の許容規定の撤廃}

強度増加促進に効果は見られるが，沈下促進には有意 な効果が見られないというのがサンドドレーンに対する 名神・東名でのデータによる評価であった．したがっ て，実用的にはサンドドレーンは，安定対策に用いると の考え方が打ち出されていたが，昭和 45 年版設計要領 では残留沈下量の許容規定值があったため, 東名以後も 実際には沈下促進のためにサンドドレーンで設計するケ ースもみられた。

このような経緯もあって，サンドドレーンの評価は引 続き大きな技術的問題であり，道央道の岩見沢試験盛土 および江別試験盛土，常磐道の神田試験盛土で無処理と サンドドレーンの比較試験が本格的に実施された.こう した経過を経て，無処理とサンドドレーンで沈下速度は 図一10 に示すように高々 2 倍程度も違わず，これは無

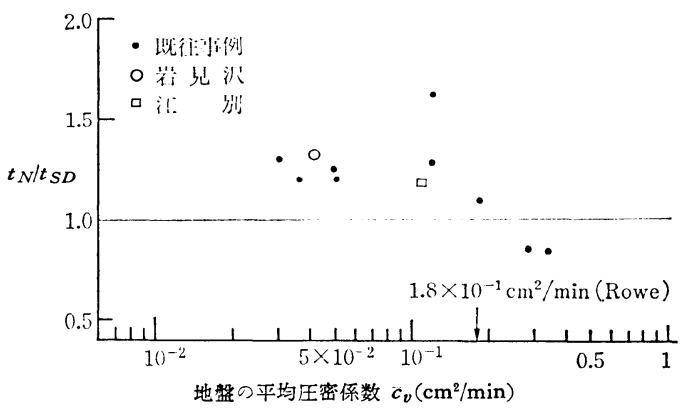

図一10 サンドドレーンが実測沈下速度に及ぼす影翠

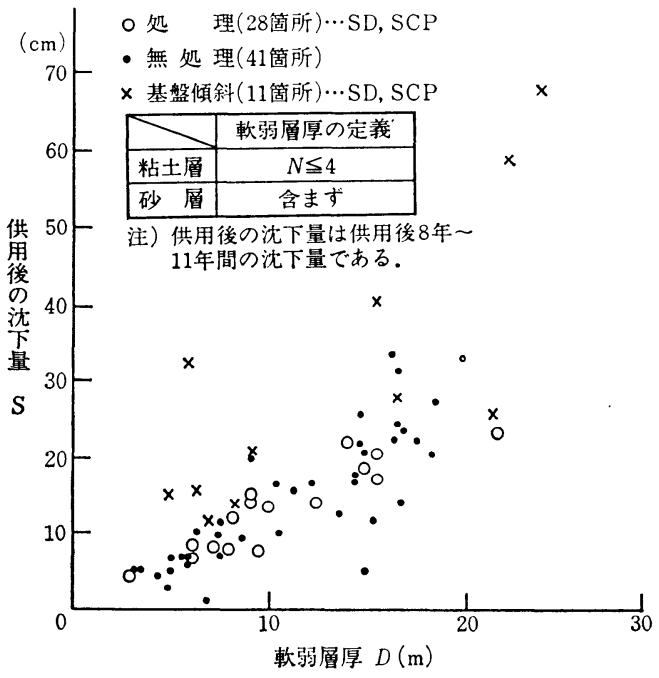

図一11 供用後の沈下量と軟弱周
処理での沈下速度がテルツァーギ理論による計算値より も相当早いことが原因であると判断された，なお，図一 10 に示す $t_{S D}$ および $t_{N}$ は実測值から曲線定規法を用 いて求めたサンドドレーン区間と無処理区間の $50 \%$ あ るいは 80\% 圧密時間を表わしており，沈下速度に反比 例する指標である。

また，図一11 に示す東名の長期沈下追跡調查からも， サンドドレーン，サンドコンパクションパイル打設の有 無にかかわらず長期にわたる残留沈下量に有意な差がな いことも判明してきた。 このほか，供用区間における補 修実態調查によると，軟弱地盤特有の補修行為は供用後 約 5 年程度までであることが多く，それ以降について は，沈下速度は遅くなり，路面の摩耗，わだち掘れなど による通常のオーバーレイでほぼ対処できることなどが 分かってきた.

さらに, 北陸道 (新泊一長周) は, 新潟平野の大規模な軟 弱地盤であり，整備された水田地帯を分断する形で高盛 土で施工されたが, 横断構造物, 近接構造物, 周辺地盤 の沈下・変形対策が重大な問題となった.このためカル バートボックスの上げ越し施工，およびそれに関連する プレロード除去時のリバウンド，近接構造物の変位防止 対策 (矢板, 砂利コンパクンョンパイル), 周辺地盤の隆起と引 き込み沈下対策などが検討された。

これらは, 常磐道, 道央道での設計・施工へ生かされ た．特に沈下対策については，施工から維持管理までの トータルコストで設計しようとする大きな発想の転換が あった. すなわち, 残留沈下量の許容規定を撤廃し, 残 留沈下には 表一3に示す方針によって対処することとし た.

\section{表一3 残 留 沈下対策}

\begin{tabular}{|c|c|c|}
\hline 区 & 方 & 対 策 \\
\hline \multirow{3}{*}{ 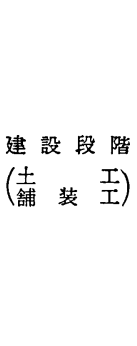 } & $\begin{array}{l}\text { (1) 可能なかきりり沈下を促 } \\
\text { 進させておく }\end{array}$ & $\begin{array}{l}\text { プレロード } \\
\text { サーチャーシ } \\
\text { 十分な放置期間ほか }\end{array}$ \\
\hline & $\begin{array}{l}\text { (2) 長期沈下に起因する支 } \\
\text { 障を吸収し5るよ5に, } \\
\text { あらかじめ余裕ある構造 } \\
\text { としておく }\end{array}$ & $\begin{array}{l}\text { 路面のかさ上げ } \\
\text { 盛土の幅員余裕 } \\
\text { カルバート断面余裕 }\end{array}$ \\
\hline & $\begin{array}{l}\text { (3) 補修の容易な構造とし } \\
\text { ておく }\end{array}$ & $\begin{array}{l}\text { 踏掛板 } \\
\text { 路面排水構造 } \\
\text { 防護さく構造ほか }\end{array}$ \\
\hline $\begin{array}{l}\text { 管 理 段 階 } \\
\text { (維持, 補修) }\end{array}$ & $\begin{array}{l}\text { (4) 沈下の進行に芯じて適 } \\
\text { 時に補修を行う }\end{array}$ & $\begin{array}{l}\text { パッチンケ } \\
\text { その他 }\end{array}$ \\
\hline
\end{tabular}

\section{（4） 新技術・新工法の試み}

盛土施工では，安定の確保が第一義的な問題であり， そのための対策工の設計および施工時の動態観測に基ゔ く安定管理には一貫して注意が払われた. 東名に続く東 北道，北陸道を皮切りに各地の軟弱地盤上の盛土工事で 
表-4 破壊予测 法

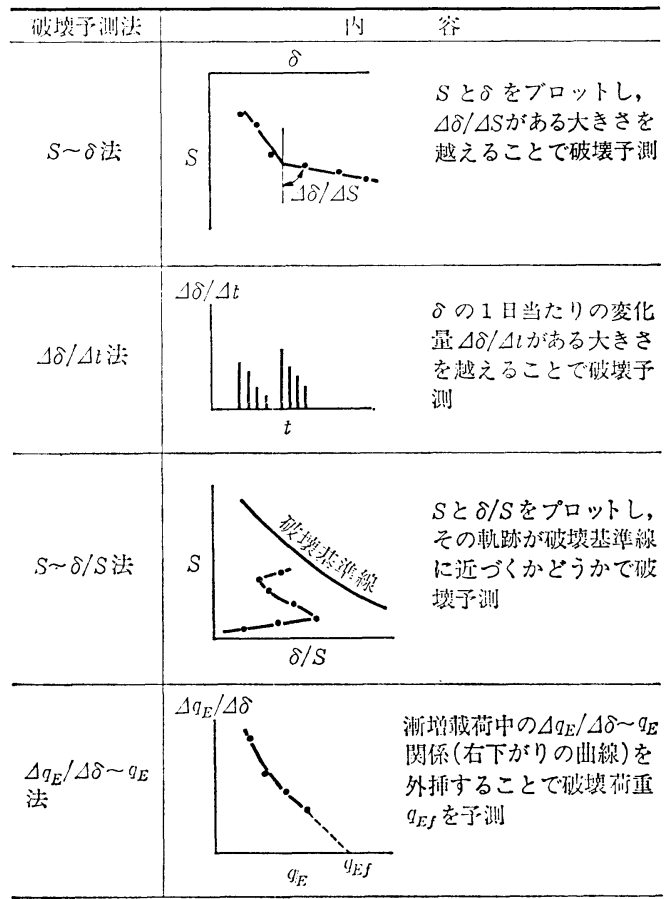

注） $S:$ 盛土中央部の沈下量

$\delta:$ 盛土のり尻部の水平交位量

$q_{E}:$ 盛土荷重

動態観測が実施された。しかしながら，観測結果から定 量的に盛土破壊を予測する手法が確立されていなかった こともあり，破壊事例も結構生じた.こうした経験から 定量的な 破壊予測手法へのニーズが高まった． 昭和 49 年頃から破壊予測法についての研究が行われ出し，いく つかの方法も提案されるようになった. 道路公団でも新 潟, 姉歯地区などで適用性のチェックが行われ始め, 道 央道・岩見沢試験盛土で本格的に検討され, 表一4 亿示 すような定量的管理手法の有効性が検証された. さら に, 道央道 (札梘一岩見沢) ではこれらを基に現場計測工法 の考え方が整備され、コンピューターを導入した情報化 施工が実施され，画期的な成果をおさめた.

新工法としては, 特殊な場合の工法として, 深層混合 処理工法が登場し, 東北道・姉歯地区における試験施工 と前後して九州道・八幡地区で側方変形対策として盛土 のり面部に施工された. 九州道・溝陸地区では, 超鋭敏 な有明粘土層を対象にした隣接構造物 (河川) 対策として 使用された. 続いて，同じ有明粘土層を対象に九州道・ 武雄地区でも近接構造物の側方変形対策として採用され た. また, 道央道・江別試験盛土では泥炭地盤での試験 施工が行われ, その有効性が確認された。

一方, サンドマット施工時にトラフィカビリティーを 確保するため敷網工法が各地で実施されたが，もっと積
極的に盛土中に補強材として用いることが試みられた. 道央道・江別試験盛土では帯鋼で盛土を補強する工法が 実施され，その有効性が確認された. 本施工としては, 東関道・佐原地区および九州道・小倉地区では金網を, 北陸道・刈羽地区では合成樹脂網をそれぞれ盛土中に多 層に敷設し, 盛土の安定をはかる工法が実施され, 成果 をおさめた。

また, サンドマットやサンドドレーンの砂の透水性 は, その効果と関連して当初から問題とされてきた. 昭 和 50 年にはサンドマットの透水性にからんで材料規定 が設けられた. その後, 道央道・岩見沢試験盛土でサン ドマットおよびサンドドレーン内での水圧残留現象が詳 細に測定され，透水性確保の重要性が明らかにされた.

\section{（5）設計要領の改訂}

新規縦貫五道の建設と名神, 東名などの維持管理での 経験を基に, 昭和 58 年 4 月に「日本道路公団設計要 領」の改訂を行った. その基本的な考え方は, 次に示す とおりである。

(1) 安定対策は緩速盛土施工を優先的に検討する.

(2) 沈下対策は十分な放㯰期間の確保など時間効果の 有効活用をはかるものとし, 残留沈下対策としての 地盤処理は, 原則として実施しない.

(3) 残留沈下対策としては, 供用後の沈下を見込んだ 道路構造の採用や将来の維持補修を前提とした設計 上の配慮を行う。

(4) 橋台および横断構造物個所には原則としてプレロ ードを行う.

(5) 施工にあたっては, 動態観測を重視し, 当初設計 の見直しや施工法の修正に活用する.

\section{あとがき}

昭和 33 年名神高速道路の建設に着手した当初, 尼崎 地区で $6 \mathrm{~m}$ の盛土をすれば $30 \mathrm{~cm}$ 沈下するといら計算 結果が得られた. 盛土が $30 \mathrm{~cm}$ も沈下した場合, 高速 走行の道路にとって壊滅的な欠陷となるであろうと恐れ た. すべり円弧法によって安全率を求めると 1 以下と計 算されていたので工事が進み, 盛土高が上るにつれて滑 り出しはしないかと関係者は皆一様に気をもんだ.

その後，1/4 世紀の間に全国各地でいろいろな経験を 積んだ.そして $4 \mathrm{~m}$ も沈下する北海道の泥炭地帯で, サンドドレーンと押え盛土といら何の変哲もないありき たりの工法を用いて，いわばたんたんとして工事を進め ることができるようになった. 当初からこれらの一連の 作業を見つめてきた者にとってまさに隔世の感がある. 本文で示したように, 大規模な軟弱地盤地帯ではすべ 
て試験盛土を実施し設計施工の指針を得てから本線工事 に着手するといら手法を採った. 予期せぬ結果がいくつ か生じたが，理論計算よりを実测結果を重視し冷静に判 断するという態度を貫いた. サンドドレーン工法を沈下 促進のためのみには使わないというのは最も大きな特色 であるが，この決断のために当初計画よりも大幅に対策 工を減らし，きわめて経済的に工事を実施得たという自 負がある。

設計要領では計算と実测との相違を指摘して，同種同 規模の軟弱地盤において注計算よりも過去の事例を参考 にして対策工を立てることを提案しているが，定量的に これらの現象を説明する普遍的な手法をなだ確立し得て いない. 各地の大学の同好の志にも集積したデータを提 供して研究してもらっているが, 現代の発達した土質力
学をもってしても, なかなかに難しく前途はまだ遠いよ うである.

\section{参考 文 献}

1）持永龍一郎：圧密による軟弱地盤の改良効果について， 土と基礴, Vol. 20, No. 8, 1972 年.

2）持永龍一郎：軟弱地盤における工事実施例. その 2 (第 2 章道路), 土質基礎工学ライブラリー 13 , 上質工学会 編, 1977 年.

3）日本道路協会：日本道路史，1977 年.

4）建設産業調查会：土木・建築技術者のための 最新缍弱地 盤ハンドブック, 1981 年.

5）栗原則夫：深い地盤改良の実際と問題点を考える，2， ハ 一チカルドレーン工法の実際と問題点 (2), 土と基礎, Vol. 30, No. 11, 1982 年.

(1984.7.31 · 受付)

\section{土木学会投稿の手引き・1984年版}

\section{A4判 90ページ・折込付録つき 1500 円(テ300 円)}

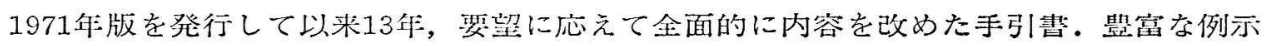
を中心にやさしく解阙した「発装のしかた」のテクニックを䛨述した。

目次○第 1 章 はじめに 1 . 投和の于河きを作った日的 2 . 原稿密查の基本的態度 3. 標準 化と情報処理 第 2 章 土木学会誌用原稿の編集の流れ 1. 原稿の受付事務 2. ページ数のチェック 3. 内容の查読 4. レイアウトの設計 5. 組版作業 6. 校正作業 7. 別刷 8. 原槅料第 3 章 土木学会誌用原稿の作成 1 . 印刷物の出来上がり任様 2 . 原稿用紙 3 . 原稿の内容と投稿区分 4. ページ数の制限 5. 数式と欧文 6. 図と写真 7. 表 8. 著作権 9. 原稿の送付 第 4 章 土 木学会論文集用原稿の作成 1 . 投稿規則の変遷 2 . 和文原稿の作成 3 . 英文原稿の作成 第 5 章 土木学会論文集（第VI部鬥）原稿の作成 1 . 編集状況と規則等 第 6 章 オフセット用原稿の作成 1. 目的 2. 活字の大きさと字数 3. 日本語ワードプロセッサーの利用，4. その他、【資料およ び付録] 資料1. ページ数計算のための数储 2. 写真・四版の割付例 3 . 写真・図版の維少割付例 4. 原稿の長さの計算用紙 5. 標準的な作四用の 下数きと作図例 6 . 著者校正 7 . 土学会誌編集方針および投稿規則 8.

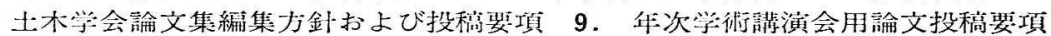
10.ワードプロセッサーを使用した原稿作成才う法 11. 研究発表会用スライド の作り才 12. 英文原稿の執筆例 13. 用字・用語のガイド 14. 記号表 15 . SI単位の筫入および表記法 16 . 管真でみる原稿が印刷されて本となるまでの 工程 17. 校正記号と校正例

[付録 1]土木学会誌用諭文送付楒，内容紹介原稿用紙，原稿用紙２．土木

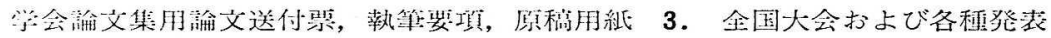

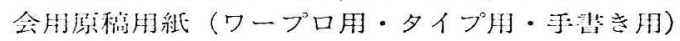

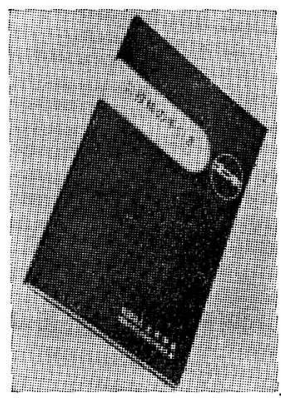

